\title{
Relationship between Radiological Severity, Knee Pain and Functional Limitation in Patients with Knee Osteoarthritis at Dr. M. Djamil Padang General Hospital
}

\author{
Yona Riapesi ${ }^{1 *}$, Rizki Rahmadian², Hendra Maska ${ }^{2}$ \\ ${ }^{1}$ General Surgery Resident of Medical Faculty - Andalas University / Dr. M. Djamil Padang General Hospital, Indonesia \\ ${ }^{2}$ Orthopaedic Department of Medical Faculty - Andalas University / Dr. M. Djamil Padang General Hospital, Indonesia
}

\section{A R T I C L E I N F O}

Keywords:

Osteoarthritis

Knee pain

Functional limitation

\section{*Corresponding author:}

Yona Riapesi

\section{E-mail address: \\ yoana.bishojo@gmail.com}

All authors have reviewed and approved the final version of the manuscript.

https://doi.org/10.32539/bsm.v5i11.365

\begin{abstract}
A B S T R A C T
Background: Osteoarthritis $(\mathrm{OA})$ is a degenerative joint disease frequently affecting the elderly and the middle class due to injury or overuse of the joints. An individual with pain due to OA will experience dysfunction of joints and muscles, thus causing movement limitation, decrease of muscle strength and balance. The objective of this study is to know the association of OA radiological degree with pain intensity and limitation of physical capability in patients with knee joint OA. Methods: This study is a retrospective study on patients with knee joint OA treated at RSUP Dr. M. Djamil Padang in year 2021 from January 2021 to May 2021. Data collection was conducted in the Medical Records Department of RSUP Dr. M. Djamil Padang and questionnaire which fulfills the inclusion and exclusion criteria. Results: A total of 58 patients fulfilled the inclusion criteria of this study. Results of the study showed the mean age of the respondents was 60 years with variance of 7 years. More than a half $(77.6 \%)$ of the respondents were female and most common ethnicity was Minang $(82.8 \%) .50 \%$ of the patients were housewives. BMI of the respondents were mostly overweight - obese (65.5\%). Most commonly affected side of the knee joint OA was the right side $(55.2 \%)$. Most common degree of OA was the fourth degree $(39.7 \%)$. More than a half of the respondents $(84.5 \%)$ had moderate intensity of pain and $34.5 \%$ respondents had mild physical limitation. Results of the study showed that there was an association between OA radiological degree and pain intensity in patients with knee joint OA ( $p$ value $=0.0001$ ). Results of the study showed that there was an association between OA radiological degree and level of physical capability limitations in patients with knee joint OA ( $p$ value $=0.0001)$. Results of the study showed that there was an association between pain intensity and level of physical capability limitations in patients with knee joint OA ( $p$ value $=0.0001)$. Conclusion: There was an association between OA radiological degree and pain intensity, physical limitations in patients with knee joint OA, and there was an association between pain intensity and level of physical capability limitation in patients with knee joint OA.
\end{abstract}

\section{Introduction}

Osteoarthritis (OA) is a degenerative joint disease that often affects the elderly and the middle ages due to injury or excessive joint use. This disorder is characterized by erosion of the articular cartilage, hypertrophy of the bone at the margins (osteophytes), subchondral sclerosis and a series of biochemical and morphological changes of the synovial membrane and joint capsule ${ }^{1}$ The clinical symptoms that can arise are joint pain, joint stiffness, swelling and redness in the joints up to limited daily activities. OA can affect various joints such as knees, hips, hands, feet, and spine. ${ }^{2}$
The prevalence of OA increases with age increasing. According to the World Health Organization (WHO), the prevalence of osteoarthritis sufferers in the world in 2011 reached 151.4 million people and 27.4 million people were in Southeast Asia. About $80 \%$ of people with OA will experience limitations in movement, and $25 \%$ of people with OA will be unable to carry out their main daily activities. It has been estimated that approximately $25 \%$ of the adult population, or more than 50 million people in the US, will be affected by this disease by 2020 and OA will be the leading cause of morbidity and disability among individuals over the age 
of 40.3

In Indonesia, the highest prevalence occurs at age > 75 years. ${ }^{4}$ From the study that held in Bandung, at the rheumatology clinic of Hasan Sadikin Hospital showed that of 2.760 cases of rheumatism in 2010, 73\% were patients with OA and $87 \%$ of cases were knee OA. ${ }^{5}$ West Sumatra is one of the provinces that has a high incidence of OA. Data from Riskesdas in 2007 showed the prevalence of OA patients in West Sumatra was ranked seventh in Indonesia and was above the national average prevalence, which reached 33\%.6

Knee pain which is the main clinical symptom of OA patients and the limitation of joint use due to the damage caused, raises the assumption that clinical symptoms have a relationship with joint damage. Pain measurement is based on the patient's personal pattern, or the conclusions drawn by the doctor based on the patient's behavior. Visual Numeric Scale (VNS) is considered as one of the most accurate methods for measuring pain. ${ }^{7}$

A person with knee pain due to OA will experience joint and muscle dysfunction so that there will be limitation of motion, decreased strength and muscle balance. Approximately 18\% experience difficulties and functional limitation, loss of function, work capacity and decreased quality of life.8,9 A cohort study conducted by Kiadaliri et al, in Southern Sweden in 2016 showed that knee OA patients with radiological abnormalities and knee pain had a lower quality of life than knee OA patients with radiological abnormalities only. ${ }^{10}$ Study conducted in 2015 at DR Hardjono Hospital - Ponorogo showed a significant relationship between the degree of pain and physical ability in patients with knee OA. ${ }^{11}$

The diagnosis of OA is usually based on clinical and radiological features. Joint radiological features that support the diagnosis of OA are joint space narrowing which is often asymmetrical, increased subchondral bone density, osteophytes at the joint margins and changes in the anatomical structure of the joint. In addition, based on the above radiographic changes, radiologically $\mathrm{OA}$ can be divided into mild to severe according to the Kellgen and Lawrence criteria. At grade 0 looks normal. In grade 1 , OA is doubtful with a normal joint appearance, but minimal osteophytes are present. In grade 2, minimal OA with osteophytes in 2 sites, no sclerosis and subchondral cysts, and good joint space. In grade 3 , moderate OA with osteophytes and deformity of the bone ends and narrow joint space. Whereas in grade 4, severe OA with large osteophytes. ${ }^{1,2}$

Based on study conducted by Asriyani (2017), it is known that there is a significant relationship between the severity of $\mathrm{OA}$ and the level of knee pain in OA patients. ${ }^{12}$ Meanwhile, from study conducted by Erminawati (2017), it is known that there is a significant relationship between the severity of OA and physical activity in patients with knee OA. ${ }^{13}$

Individual pain perception is influenced by various factors such as age, gender and socio-culture, so we are interested in seeing whether the same or different results will be obtained with previous studies conducted in different socio-cultural settings. Therefore, in this study we were assessing the relationship between radiological degrees of OA with pain intensity and physical limitations in knee joint OA patients at Dr. M. Djamil Padang General Hospital.

\section{Methods}

Retrospective data were collected from knee OA patients between January 2021 to May 2021. The data of knee OA patients who met the inclusion and exclusion criteria who were treated at Dr. M. Djamil PadangGeneral Hospital was used for analysis. The sample was taken from the population using the formula of the two-proportion hypothesis. The inclusion criteria in this study were knee joint OA patients who came to the Orthopedic Polyclinic, in January 2018 to December 2020, had been performed the X-ray of the knee joint (where the X-ray are interpreted by the same radiologist for all research samples), and was willing to be the subject of the study and answer the questions on the questionnaire. While the exclusion criteria in this study were patients with knee joint OA with a history of trauma to the knee joint, did not have an X-ray of the knee joint, had a disease or other complications that hindered the patient's daily physical abilities (other musculoskeletal diseases, 
diseases or abnormalities in the spine), and was a patient with bilateral knee joint OA.

The data was obtained by taking data from the Medical Record of Dr. M. Djamil Padang General Hospital and questionnaires filled out by respondents. The results were obtained by collecting datas on age, gender, ethnicity, occupation, Body Mass Index (BMI), the side of the knee affected by OA, the severity of knee OA based on Kellgen Lawrence grading, knee pain intensity and physical limitations based on Oxford Knee Score (OKS). The data was processed and analyzed using SPSS version 22. Univariate analysis was conducted to see the frequency distribution for categorical data. Bivariate analysis was carried out using the Pearson Chi-square test to see the relationship between OA severity, knee pain intensity and functional limitations, as well as the relationship between knee pain intensity and finctional limitations in knee OA patients. The results of the study are significant related if the $\mathrm{p}$-value $<0.05$. This study has met the ethical approval, with serial number: $157 / \mathrm{KEPK} / 2021$.

\section{Result}

Table 1, the characteristics of patients with knee joint OA shows that $22.4 \%$ of respondents are male and $77.6 \%$ are female. the average age of the respondents was 60 years with 7 years variation. More than half $(77.6 \%)$ of the respondents were women and the most ethnic group was Minang (82.8\%). 50\% of patients work as housewives. Most of the respondents BMI was overweight - obese (65.5\%). The most site of the knee OA was on the right side (55.2\%). The highest severity type of OA was grade 4 (39.7\%). More than half of respondents $(84.5 \%)$ had moderate pain intensity and $34.5 \%$ of respondents had mild functinal limitations.

Table 1. Characteristics of Knee OA Patients

\begin{tabular}{|c|c|c|}
\hline Variable & $\mathbf{N}$ & $\%$ \\
\hline Age & $59,57 \pm 7,42$ & \\
\hline \multicolumn{3}{|l|}{ Sex } \\
\hline Male & 13 & 22,4 \\
\hline Female & 45 & 77,6 \\
\hline \multicolumn{3}{|l|}{ Ethnic Group } \\
\hline Minang & 48 & 82,8 \\
\hline Melayu & 9 & 15,5 \\
\hline Chinese & 1 & 1,7 \\
\hline \multicolumn{3}{|l|}{ Occupation } \\
\hline Housewife & 29 & 50,0 \\
\hline Civil servants & 22 & 37,9 \\
\hline Private sector & 7 & 12,1 \\
\hline \multicolumn{3}{|l|}{ BMI } \\
\hline Normal & 20 & 34,5 \\
\hline Overweight - obesity & 38 & 65,5 \\
\hline \multicolumn{3}{|l|}{ Side of knee OA } \\
\hline Right & 32 & 55,2 \\
\hline Left & 26 & 44,8 \\
\hline \multicolumn{3}{|l|}{ OA Severity Grade } \\
\hline 1 & 0 & 0 \\
\hline 2 & 15 & 25,9 \\
\hline 3 & 20 & 34,5 \\
\hline 4 & 23 & 39,7 \\
\hline \multicolumn{3}{|l|}{ Knee Pain Intensity } \\
\hline Mild & 6 & 10,3 \\
\hline Moderate & 49 & 84,5 \\
\hline Severe & 3 & 5,2 \\
\hline \multicolumn{3}{|l|}{ Functional Limitation } \\
\hline No limitation & 16 & 27,6 \\
\hline Mild & 20 & 34,5 \\
\hline Moderate & 18 & 31,0 \\
\hline Severe & 4 & 6,9 \\
\hline
\end{tabular}


Table 2 shows that the highest proportion of OA grade 2 is in the moderate pain intensity group, which is $60 \%$. At the OA grade 3 group, $100 \%$ of the subjects experienced moderate knee pain intensity and $87 \%$ were also in the OA grade 4 group. The results of statistical tests showed that there was a relationship between the severity of OA and the intensity of knee pain in knee OA patients ( $\mathrm{p}$-value $=0.0001$ )

Table 2. Relationship between OA Severity and Knee Pain Intensity In Knee OA Patients

\begin{tabular}{|c|c|c|c|c|c|}
\hline \multirow{3}{*}{$\begin{array}{c}\text { OA } \\
\text { Severity }\end{array}$} & \multicolumn{3}{|c|}{ Pain Intensity } & \multirow{3}{*}{$\begin{array}{l}\text { Total } \\
\text { N (\%) }\end{array}$} & \multirow{3}{*}{ p-value } \\
\hline & Mild & Moderate & Severe & & \\
\hline & n (\%) & n (\%) & n (\%) & & \\
\hline 2 & $6(40,0)$ & $9(60,0)$ & 0 & $15(100)$ & 0,0001 \\
\hline 3 & 0 & $20(100)$ & 0 & 20 (100) & \\
\hline 4 & 0 & $20(87,0)$ & $3(13,0)$ & $23(100)$ & \\
\hline
\end{tabular}

Table 3 shows that the highest proportion of OA grade 2 is in the no limitations group, which is $80 \%$. At the OA grade 3 group, there were $45 \%$ of subjects who had mild limitations. And in the OA grade 4 group, $43.5 \%$ of the subjects had moderate limitations. The results of statistical tests showed that there was a relationship between the severity of OA and the level of functional limitations in knee OA patients $(\mathrm{p}$-value $=$ $0.0001)$.

Table 3. Relationship betweeen OA Severity and Functional Limitation In Knee OA Patients

\begin{tabular}{|c|c|c|c|c|c|c|}
\hline \multirow{3}{*}{$\begin{array}{c}\text { OA } \\
\text { Severit } \\
y\end{array}$} & \multicolumn{4}{|c|}{ Functional Limitation } & \multirow{3}{*}{$\begin{array}{l}\text { Total } \\
\text { N (\%) }\end{array}$} & \multirow{3}{*}{ p-value } \\
\hline & No limitation & Mild & Moderaate & Severe & & \\
\hline & n (\%) & n (\%) & n (\%) & n (\%) & & \\
\hline 2 & $12(80,0)$ & $3(20,0)$ & 0 & 0 & $15(100)$ & 0,0001 \\
\hline 3 & $3(15,0)$ & $9(45,0)$ & $8(40,0)$ & 0 & $20(100)$ & \\
\hline 4 & $1(4,3)$ & $8(34,8)$ & $10(43,5)$ & $4(17,4)$ & $23(100)$ & \\
\hline
\end{tabular}

Table 4 shows that the $100 \%$ of the mild knee pain group subjects experience no functional limitations. At moderate knee pain group, $40.8 \%$ of subjects experienced mild limitations. And in the severe knee pain group, $66.7 \%$ of the subjects experienced severe functional limitations. The results of statistical tests showed that there was a relationship between knee pain intensity and the level of functional limitations in knee OA patients $(\mathrm{p}$-value $=0.0001)$.

Table 4. Relationship between Knee Pain Intensity and Functional Limitations In Knee OA Patients

\begin{tabular}{lcccccc}
\hline \multirow{2}{*}{$\begin{array}{c}\text { Pain } \\
\text { Intensity }\end{array}$} & \multicolumn{3}{c}{ Functional Limitation } & \multirow{2}{*}{ Total } & \multirow{2}{*}{ p-value } \\
\cline { 2 - 5 } & No limitation & Mild & Moderaate & Severe & N (\%) & \\
\hline Ringan & $\mathbf{n ~ ( \% )}$ & $\mathbf{n ~ ( \% )}$ & $\mathbf{n ~ ( \% )}$ & $\mathbf{n ~ ( \% )}$ & & 0,0001 \\
Sedang & $6(100)$ & 0 & 0 & 0 & $2(100)$ & $0,000)$ \\
Berat & $10(20,4)$ & $20(40,8)$ & $17(34,7)$ & $2(4,1)$ & $49(100)$ & $3(100)$ \\
\hline
\end{tabular}

In the group with the classification of mild, moderate, moderate-severe, and severe hearing loss, more groups experienced hearing improvement than those without hearing improvement. In the group with a very severe degree of hearing loss, $66.7 \%$ of the patient did not experience an improvement in therapy results. From the analysis results, there was no significant relationship between the degree of hearing loss and the outcome of therapy $(\mathrm{p}=0.288)$. 


\section{Discussion}

In this study, 58 patients were included in the inclusion criteria. The age of the respondents in this study had a mean of 60 years with 7 years variance. The results of this study are in accordance with the epidemiological study conducted by Safiri, et.al (2020), in a global systematic analysis, which stated that in 2017 the global incidence of OA increased with increasing age, especially in the age group over 55-59 years. ${ }^{14}$ The existence of increasing age as a risk factor for OA is supported by the theory that in the aging process there is a loss of the ability of cells and tissues to maintain homeostasis, especially when the joints are subjected to abnormal stresses such as oxidative stress or excessive biomechanical stress on the joints. This increases the aging of chondrocytes due to stress. Aging also involves the formation of advanced glycation end products that are produced in aging tissue. These end products alter the mechanical properties of cartilage, which transforms into a more brittle tissue with increased fatigue, and stimulate the overproduction of pro-inflammatory cytokines and Matrix metallopproteinases (MMPs). In elderly patients with OA there is a positive relationship between knee pain, limb weakness, and sarcopenia. Although the inflammation that occurs in age-related OA may not directly cause OA but tends to act as a contributing factor the disease progression, as well as increased knee pain and decreased physical function. ${ }^{15}$

Based on the sex graoup, the data analysis showed that the incidence of knee OA was more common in female than male. The incidence of knee OA in female was 45 patients $(77.6 \%)$ and in male was $13(22.4 \%)$. The results of this study are in accordance with the results of study conducted by Safiri S et.al (2020), where the incidence of OA is higher in women and also increases with age increasing. ${ }^{14}$ Studies have linked estrogen supplementation with a reduced risk of OA, which may explain how decreased estrogen in postmenopausal women may contribute to the incidence and severity of OA seen in women compared to men. Gender differences were seen in the tissues affected by OA. Not only there are differences in synovial fluid composition, but chondrocytes and osteoblasts isolated from cartilage and bone affected by OA also differ. As well as the sex-associated hormone receptor expression and different responses to 1a,25(OH)2D3, 24R, 25(OH)2D3, E2, and DHT (Dihydrotestosterone). In addition, articular chondrocytes from male and female patients showed differences in gene expression for inflammatory cytokines, enzymes involved in matrix degradation in the regulation of articular chondrocyte proliferation and differentiation. 16

From the analysis of data based on ethnicity, it was found that the majority of respondents came from the Minang ethnic group with a total of 48 patients $(82.8 \%)$, followed by the Melayu with 9 patients (15.5\%) and 1 patient from the Chinese ethnic group. (1.7\%). This result is probably because the study was conducted based on data of patients who came to Dr. M. Djamil General Hospital whose majority of patients are from the Province of West Sumatra with the Minang ethnicity.

Based on data analysis of the respondents occupations, it was found that $50 \%$ were housewives (29 patients) followed by $37.9 \%$ worked as civil servants (22 patients) and $12.1 \%$ worked in the private sector $(7$ people). These results are in accordance with study conducted by Srilekha C and Kumar (2019) in South India regarding several jobs related to osteoarthritis, it was found that the housewifes group experienced more osteoarthritis, which was $24.5 \%$ of the entire study sample. As well as the results of study by Mahfouz, et al (2019), namely the highest percentage of OA in the hip joint is from the housewifes group with a percentage reaching $43.6 \%$ compared to other occupations such as students, teachers, military soldiers, health workers, freelancers, and the unemployed, and this housewifes group also experienced symptoms of difficulty in moving related to OA. ${ }^{17,18}$ the predictives factors caused OA in housewifes are mentioned in the study of Abdelnasser, et al in 2020 which also found that the incidence of OA was most experienced by housewifes, which was $58 \%$ due to the burden of household work. ${ }^{19}$

From the results of data based on BMI, the highest incidence of OA was found in the overweight - obesity 
group with 38 patients $(65.5 \%)$. These results are consistent with a meta-analysis study conducted by Zheng et al (2015), which found that overweight or obese patients had an approximately 2.5-4.6 times risk of developing OA than the normal BMI group. The risk of OA will increase by $35 \%$ with an increase in BMI of $5 \mathrm{~kg} / \mathrm{m} 2 .{ }^{20}$ Obesity is the strongest risk factor for knee OA. The effect of obesity on the development and progression of OA is mainly through increased load on weight-bearing joints. Three to six times body weight is applied to the knee joint when the body is resting on one leg. An increase in body weight will double the burden on the knee joint when walking which causes cartilage damage. ${ }^{21}$

From the data analysis on the knee OA side, the highest incidence of OA was found on the right knee, which was $55.2 \%$. These results are in accordance with the research conducted by Hafizh et al in Semarang (2015), which also found that the highest incidence of knee OA occurred in the right knee. ${ }^{22}$ This can be caused by the tendency of patients to make the right foot as the main support or the dominant foot in carrying out activities, which is also supported by study conducted by Mirjana, et al (2016), which states that this is related to dominance in one of the hemispheres of the brain that play a role in carrying out certain functions. Functionally, the brain shows laterality to both hemispheres of the brain which simultaneously play a role in carrying out an activity but one hemisphere will become more dominant in certain aspects. 23

Based on data analysis on the severity of knee OA, the most results were grade 4 with 23 patients (39.7\%) and in the second place was grade 3 with 20 patients $(34.5 \%)$ and in third place was grade 2 with 15 patients $(25.9 \%)$. The results of this study are in line with study conducted by Jamalullail $S$ in 2017 at the Hassanuddin University Hospital in Makassar which also found that most knee joint OA sufferers were at grade 3.12 In this study, there were no samples of respondents from the OA grade 1 category, so that the assessment of knee pain intensity and functional limitations cannot be obtained. This can be caused by the tendency of people who are sometimes reluctant to look for treatment when the symptoms of the disease are still mild, as well as the factor of Dr. M. Djamil Padang Ggeneral Hospital as a referral center for reveral hospitals, so that early cases can be treated at referral hospitals and only moderate-severe cases are referred.

In the results of data analysis of the relationship between severity of $\mathrm{OA}$ and knee pain intensity, statistically significant results were obtained $(\mathrm{p}$-value $=$ $0.0001)$. This is in accordance with study conducted by Ozden, et al (2020), that there is a significant relationship between the severity of OA and the knee pain felt when doing activities. ${ }^{24}$ This study also showed that the highest proportion of grade 2 OA was in the moderate pain intensity group, which was $60 \%$. In OA grade 3 there are $100 \%$ of research subjects who experience moderate knee pain intensity and $87 \%$ are also in the OA grade 4 category. These results are also in accordance with study conducted by Ribeiro, et al which concluded that the increase in the degree of OA is directly proportional to the increase in pain intensity. 25

Based on the relationship between severity of OA and functional limitation in knee OA patients, it was found that the highest proportion of category OA grade 2 group was no limitations (80\%). At the third OA grade 3 , there were $45 \%$ of subjects who had mild limitations. And in the OA grade 4 group, $43.5 \%$ of the subjects had moderate limitations. The results of statistical tests showed that there was a relationship between the severity of OA and the level of functional limitations in knee OA patients $(\mathrm{p}$-value $=0.0001)$. This is in line with study conducted by Ribeiro, et al (2020), which obtained the results that there was a significant relationship between the severity of OA and several indicators including knee pain, stiffness and limitations of physical activity. ${ }^{25}$ These results are also in accordance with study conducted by Fabunmi, et al (2019), which is that there is a significant relationship between the degree of OA of the knee joint and limited physical abilities. ${ }^{26}$

Based on the relationship between knee pain intensity and the level of functional limitation in OA patients, it was found that the proportion of the mild 
pain intensity was highest in the no limitations group (100\%). At moderate knee pain intensity there were $40.8 \%$ of subjects who experienced mild limitations. And in the severe knee pain intensity group, $66.7 \%$ of the subjects experienced severe limitations. The results of the statistical test showed that there was a relationship between knee pain intensity and the level of functional limitations in knee OA patients $(p$-value $=$ 0.0001). The results of this study are in accordance with research conducted by Kurniawan F in 2016 at Dr. R. M. Soedrarwadi General Hospital in Klaten, who also stated that there was a significant relationship between the quality of pain and the functional activity ability of patients with knee OA. ${ }^{27}$

\section{Reference}

1. Cesare P, Haudenschild D, Samuels J, Abramson S. Pathogenesis of osteoarthritis (Chapter 98). In: Firestein GS, Budd RC, Gabriel SE, McInnes IB, O’Dell JR. Kelley and Firestein's textbook of rheumatology. 10th ed. Philadelphia, PA: Elsevier; 2017. p.1685-702.

2. Kean WF, Kean R, Buchanan WW. Osteoarthritis: Symptoms, signs and source of pain, Inflammopharmacology Journal, pp. 331. 2004.

3. Fransen $M$ et al. The epidemiology of osteoarthritis in Asia. 2011. (diakses 21 Januari 2021). http://www. ncbi.nlm.nih.gov/pubmed/2151830.

4. Tim Riskesdas Kemenkes RI. Riset Kesehatan Dasar (RISKESDAS). Jakarta: Balitbang Kemenkes RI; 2013.

5. Rekomendasi Perhimpunan Reumatologi Indonesia. Diagnosis dan penatalaksanaan osteoartritis. Jakarta: Indonesia Rheumatology Association; 2014.

6. Tim Riskesdas Kemenkes RI. Laporan RISKESDAS 2018 Provinsi Sumatera Barat. Jakarta: Balitbang Kemenkes RI; 2019.

7. Flynn D, van Schaik $P$, vanWersch A. A comparison of multi item and visual analogue scales for the assessment of transactionally defined coping. Eur J Psychol Assess.
2004;20:49-58.

8. Reis et. Al. Evaluation of postural control and quality of life in elderly women with knee osteoarthritis. Brazil. Revista Brasileira de Reumatologia 54: 2014. p.208-21.

9. Kuntuno, Heru. Nyeri secara umum dan osteoartritis lutut dari aspek fisioterapi. Perpustakaan nasional RI. Surakarta: 2011.

10. Kiadaliri AA, Lamm CJ, de Verdier MG, Engström G, Turkiewicz A, Lohmander LS, dkk. Association of knee pain and different definitions of knee osteoarthritis with healthrelated quality of life : a population- based cohort study in southern Sweden. Health Qual Life Outcomes. 2016;14(1):121.

11. Amanda TT. Hubungan derajat nyeri dengan kualitas hidup pasien osteoartritis di poli syaraf rumah sakit umum daerah Dr. Hardjono Ponorogo. Surakarta: 2015.

12. Asriyani S, Ali SJ. Hubungan antara derajat radiologi menurut kellgren dan lawrence dengan tingkat nyeri pada pasien osteoartritis genu di RS Universitas Hasanuddin. Makassar: 2017.

13. Erminawati. Hubungan antara nyeri lutut osteoartritis dengan aktivitas fisik lanjut usia. Surakarta: 2017.

14. Safiri S, et al. Global, regional and national burden of osteoarthritis 1990-2017: a systematic analysis of the Global Burden of Disease Study 2017. Ann Rheum Dis 2020;0:1-10.

15. Valdes AM, Stocks J. Osteoarthritis and ageing. European medical journal. 2018.

16. Pan Q, et al. Characterization of osteoarthritic human knees indicatws potensial sex differences. Biology of Sex Differences. 2016;7:27.

17. Srilekha C, Kumar CP. The study one prevalence and management of osteoarthritis in South India. International journal of orthopaedics science. 2019;5(4):112-117.

18. Mahfouz MEM, et al. Osteoarthritis patient's comorbidiy and lifestyle: a cross-sectional 
study in the Saudi population. IJDMC. 2019;3(2):001-007.

19. Abdelnasser $\mathrm{N}$, et al.The relationship between environtmental factors and health-related functional disability of older adults with osteoarthritis. Advances in health sciencea research. 2020;3.

20. Zheng $\mathrm{H}$, Chen $\mathrm{C}$. Body mass index and risk of knee osteoarthritis: systematic review and meta- analysis of prospective studies. BMJ Open. 2015.

21. Grazio S, Balen D. Risk factors and predictor of osteoarthritis. Lijec vjesn. 2009;131:22-6.

22. Hafizh M, Tanti AK. Gambaran kualitas hidup dan tingkat kecemasan pasien osteoartritis lutut di instalasi rehabilitasi medik RSUP dr. Kariadi Semarang. H Media Medika Muda. 2015; 5:1254-1255.

23. Mirjana D, Vesna I, Vojkan N, Zvezdan M, Dragica P, Sonja S, et al. The importance of functional hemispheric asymmetry in the assessment of cognitive evoked potentials and reaction time. Praxis Med. 2016;45(2):77-82.

24. Ozden $\mathrm{F}$, et al. The relationship of radiographic findings with pain, function, and quality f life in patients with knee osteoarthritis. JCOT. 2020.

25. Ribeiro IC, et al. Relationship between radiological severity and physical and mental health in elderly individuals with knee osteoarthritis. Arthritis Research \& Therapy. (2020) 22:187.

26. Fabunmi AA, et al. Pattern of physical activity level, pain intensity, range of motion and physical function among older patients with knee osteoarthritis. Int $\mathrm{J}$ Phys Med Rehabil. 2019;7(5): 2-4.

27. Kurniawan F. Hubungan antara kualitas nyeri dengan kemampuan aktivitas fungsional penderita osteoartritis lutut di RSUD Dr. R. M Soedjarwadi. Klaten: 2016. 